\title{
VUOROVAIKUTUSILMIÖT TYÖNOHJAUKSESSA
}

\begin{abstract}
Työnohjauksen perimmäinen tavoite on se, että ohjattava oppii kunnioittamaan omaa osaamistaan ja osaa asettaa realistisia kehittymisen tavoitteita omalle toiminnalleen. Työnohjaus voi olla merkittävä ammatillisen kehittymisen vauhdittaja. Mutta miten asiantuntijatyön työnohjauksessa voitaisiin hyödyntää sitä työnohjauksen tutkimusta ja niitä käytäntöjä, joita on saatu psykoterapiatyössä? Perinteisen psykoanalyyttisen lähestymistavan vakiintuneet käsitteet, kuten vastustus tai transferenssi, kuvaavat vuorovaikutusilmiöitä, jotka liittyvät työnohjaukseen yleisemminkin.
\end{abstract}

\section{JUHANI TIURANIEMI}

$\mathrm{T}$ yönohjauksen käyttö sekä työyhteisön toiminnan tukemiseksi että asiantuntijoiden koulutuksen osana on lisääntynyt viime vuosina huomattavasti. Myös työnohjauksen tutkimus on vastaavasti lisääntynyt (Ellis, Ladany, Krengel and Schult 1996, Freitas 2002, Suomessa Hyrkäs 2002, Keskinen 2002, PaunonenIlmonen 2001). Moni asiantuntija käyttää työnohjausta työvälineenään eri yhteyksissä, ja toisaalta monen asiantuntijan oman työn kehittämisen välineenä on saatu työnohjaus. Työnohjausta käytetään muun muassa esimiesten ja opettajien toiminnan tukena sekä työyhteisöjen toiminnan kehittämisessä. Tässä artikkelissa tarkastellaan, miten psykoterapiatyöhön saadun työnohjauksen tutkimus ja käytäntö on hyödynnettävissä muussa asiantuntijatyönohjauksessa. Tarkastelussa lähdetään liikkeelle psykoterapiatyön työnohjauksesta ja siihen liittyvästä tutkimuksesta erityisesti kognitiivisesta viitekehyksestä, mutta myös psykodynaamisesta. Erityisesti pohditaan psykoterapian työnohjauksen kokemusten käyttöarvoa laajemminkin työnohjauksen piirissä. Työnohjausta tarkastellaan vuorovaikutusprosessina. Vuorovaikutukseen liittyvät ilmiöt voivat olla ohjauksen esteitä, mutta myös tärkeitä informaation lähteitä.

\section{TYÖNOHJAUS JA MUUT TYÖN KEHITTÄMISEN VÄLINEET}

Työnohjaus voidaan määritellä kokeneemman ja nuoremman asiantuntijan sopimukseen perustu- vaksi tavoitteelliseksi yhteistyöksi, joka toteutetaan säännöllisenä ja määräaikaisena ja jossa käsitellään ohjattavan työhön liittyviä ilmiöitä. Sen yleistavoitteena on ohjattavan ammatillinen oppiminen, kasvu ja kehitys sekä työssä jaksaminen. Työnohjaus voidaan toteuttaa yksilö- tai ryhmätyönohjauksena.

Mentorointi on kehitetty yksityissektorilla, ja se voidaan määritellä kokeneemman ja nuoremman asiantuntijan sopimukseen perustuvaksi tavoitteelli-

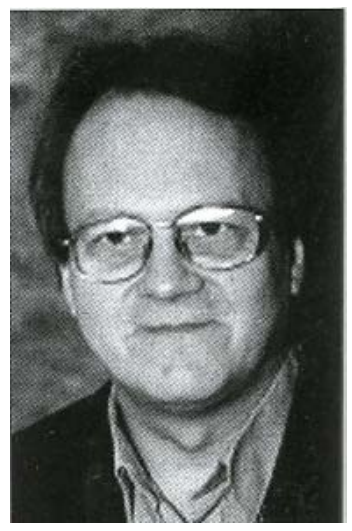

Juhani Tiuraniemi seksi yhteistyöksi, joka toteutetaan vapaamuotoisena ja jossa yleistavoitteena on tukea ohjattavaa erityisesti urakehityksessä sekä siirtää kokemuksia ja näkemyksiä ohjattavalle. Mentoroinnin toteutuksen muodot voivat vaihdella huomattavasti (Johnson 2002). Konsultaatio puolestaan on kertaluonteinen tapahtuma, jossa toinen asiantuntija kysyy toisen asiantuntijan mielipidettä omasta työtilanteestaan, tavallisemmin potilaan tai asiakkaan tilanteeseen liittyvästä asiasta. Työnohjauksen luonteinen konsultaatio puolestaan tarkoittaa tilannetta, jossa työskennellään työnohjauksen luonteisesti, mutta ammatilliseen kasvuun liittyvät tavoitteet eivät korostu. Psykoterapiassa puolestaan korostuvat hoidolliset tavoitteet, ja se eroaa selvimmin edellä mainituista. Näissä kaikissa työmuodoissa on kuitenkin paljon yhteisiä piirteitä ja yleensä psykotera- 
peutin toiminta on ollut esikuvana työnohjaajan, mentorin tai konsultin toiminnassa.

Työnohjaustapahtumaa voidaan jäsentää tarkastelemalla sitä sen mukaan, mikä kulloinkin on työnohjauksen fokuksessa. Ensisijaisesti työnohjauksessa tarkastellaan ohjattavan asiakkaan tilannetta (yksittäinen henkilö, ryhmä tai esimerkiksi työyhteisö). Tällöin psykoterapian työnohjauksessa pyritään ensisijaisesti ymmärtämään potilaan sisäistä maailmaa ja vastaavasti työyhteisön työnohjauksessa pyritään ymmärtämään työyhteisön sisäistä dynamiikkaa ja ryhmäprosesseja. Toiseksi fokus voi olla myös työmenetelmissä, joita ohjattava käyttää asiakkaan tilanteen auttamiseksi tai muuttamiseksi. Esimerkiksi esimiehen työnohjauksessä pohditaan ohjattavan käyttämiä johtamismenetelmiä ja niiden toimivuutta työyhteisössä. Kolmantena kohteena voi olla ohjattavan suhde asiakkaaseen, koska suhdetekijät voivat määritellä, mitä ylipäätään voidaan tilanteessa tehdä. Neljäs fokus on ohjattavan sisäinen maailma ja hänen toimintaympäristönsä. Tällöin pyritään hyödyntämään ohjattavan sisäisten kokemusten informaatioarvoa sekä pohditaan ohjattavan toimintaympäristön vaikutuksia tilanteeseen.

Myös työnohjaustilanne, erityisesti tavoitteiden asettelu, vuorovaikutuksen ongelmat tai ohjaustoiminnan arviointi, edellyttää toisinaan yhteistä tarkastelua. Työnohjaussuhteen luottamuksellisuus vaikuttaa siihen, mitä ohjattava kokee voivansa kertoa työnohjaajalleen. Myös työnohjaajan sisäisillä tapahtumilla on informaatioarvoa, jota voidaan hyödyntää ohjattavan työn tarkastelun näkökulmasta (Tiuraniemi 2002).

\section{VASTUSTUS TYÖNOHJAUKSEN ILMIÖNÄ}

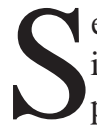

euraavaksi työnohjauksen vuorovaikutusilmiöitä tarkastellaan erityisesti psykotera pian työnohjauksen näkökulmasta. Alkuvaiheen periaatteita luotiin psykoanalyyttisen viitekehyksen pohjalta, jolloin työnohjaus nähtiin analogiana psykoanalyysiin (Davy 2002). Tällöin työnohjauksen tavoitteena pidettiin ohjattavan oivalluksen kehittymistä, vastatransferenssin kanssa työskentelyä sekä tiedostamattoman vuorovaikutuksen tiedostamista. Fokus oli ensisijaisesti ohjattavan sisäisessä ja nimenomaan tiedostamattomassa maailmassa. Taustaoletus oli, että terapeutin tiedostamaton on terapiaproses- sin kannalta "vaarallista” ja työnohjauksen avulla pyrittiin saamaan torjuttu "vaarallinen" aines tietoiseksi. Tämä asennoituminen työnohjaukseen voi johtaa ohjattavan kannalta hankalaan tilanteeseen ja kuvaa työnohjauksen keskeistä uhkakuvaa: miten ohjattava uskaltaa tuoda esille omia osaamattomuuden ja avuttomuuden tunteitaan, jos se on vaarallista työssä. Seurauksena voi olla passiivisuus sekä työssä että työnohjauksessa: kun varoo tekemästä virheitä, niin parhaiten niitä välttää passiivisuudella.

Toisaalta omien tiedostamattomien tekijöiden tunnistaminen voi olla myös hyvin houkutteleva vaihtoehto, joka aktivoi ja motivoi työnohjaukseen. Työnohjaus onkin ristiriitainen mahdollisuus ohjattavalle: toisaalla ovat uhkakuvat oman haavoittuvuuden paljastumisesta ja toisaalla mahdollisuus oman persoonan kehittämiseen. Oman osaamattomuuden ja avuttomuuden esille tuomisen mahdollisuus on ensisijaisen tärkeää työnohjauksessa. Modernissa psykodynaamisessa lähestymistavassa onkin korostettu periaatteita, jotka korostavat vuorovaikutuksellisuutta ja aktiivisuutta passiivisuuteen suuntaavien periaatteiden sijaan (Mitchell 2000, McKinney 2000).

Psykoanalyyttisen perinteisen lähestymistavan perusteella ovat vakiintuneet käsitteet vastustus, täydentävät tunnereaktiot, paralleeliprosessi, transferenssi ja vastatransferenssi sekä projektiivinen identifikaatio, jotka ovat tärkeitä myös työnohjauksessa (Corn 2001). Nämä käsitteet kuvaavat vuorovaikutuksen perusilmiöitä, jotka liittyvät yleensäkin työnohjaukseen. Nykyisessä psykoanalyyttisessä työnohjauksessa korostetaan positivistisen auktoriteettikeskeisen ajattelutavan sijaan postmodernia näkemystä todellisuuden konstruktiivisesta hahmottamisesta ja vuorovaikutuksellisesta ilmiöiden merkityksestä (McKinney 2000). Tämä lähestymistapa luo perustaa myös integratiiviselle työnohjauksen tarkastelulle, sillä samat näkökulmat korostuvat myös kognitiivis-konstruktiivisessa lähestymistavassa (Guidano 1991).

Vastustus ei liity pelkästään henkilöön. Vastustus on vuorovaikutuksellinen ilmiö, joka ilmenee kahden henkilön välisessä tilassa (Aron 1996). Vastustus voidaan nähdä moniulotteisena prosessina, jossa terapeutti voi liittoutua vastustuksen kanssa (Liotti 1991). Esimerkiksi jos potilas toteaa, että hän ei halua puhua jostakin asiasta, niin terapeutti tukee potilastaan ja toteaa, että asian käsittely voi aiheuttaa kipua ja että siihen 
voi palata ehkä myöhemmin.

Työnohjauksessa vastustuksen eri muodot voivat ilmetä eri tavoin. Validoinnin vastustus (Leahy 2001) tarkoittaa työnohjauksessa ohjattavan toimintoja, jotka ilmaisevat negatiivisesti ohjattavan tarvetta tulla työnohjaajan ymmärtämäksi. Keskeisiä vastustuksen muotoja työnohjauksessa ovat esimerkiksi työhön liittyvien vaikeuksien korostaminen ilman niiden tarkempaa tarkastelua, pyrkimys saada aikaan negatiivisia tunteita työnohjaajassa ("tästä ei tule mitään”), emotionaalisen etäisyyden ylläpito ja epäsuora vetoaminen johonkin toiseen henkilöön ("tämä työongelma täytyy ratkaista muualla kuin työnohjauksessa”. Ohjattava voi olla haluton puhumaan omista tarpeistaan. Hän saattaa nähdä osaamattomuuden ja haavoittuvuuden tunteet heikkoutena tai hän voi vähätellä omia tarpeitaan (vrt. Leahy 2001). Tällöin työnohjaajan on pyrittävä miettimään, miten menetellä vastustuksen kanssa. Keskeistä on luoda riittävän turvallinen ilmapiiri haavoittuvuuden ja osaamattomuuden tunteiden käsittelyyn. Ohjattava on oppimistilanteessa, jossa joutuu kohtaamaan omaa osaamattomuuttaan. Vastustus on siten luonnollinen ilmiö työnohjauksessa ja vastustuksen kautta ohjattava ilmaisee negatiivisesti tarvettaan saada ymmärrystä työnohjaajalta.

Muutoksen vastustus ilmenee usein negatiivisen minuuden kokemuksen ylläpitämisenä: henkilö voi olla ahdistuneen valittava kykenemättä tarkastelemaan omaa olotilaansa ja negatiivinen tila jatkuu. Ohjattava voi kokea senhetkisen työtapansa ahdistavana, mutta muutos edustaa jotakin suurempaa uhkatekijää. Taustalla on pyrkimys ylläpitää minuuden jatkuvuuden tunnetta, koska uuden ajattelu- ja toimintatavan omaksuminen merkitsee myös henkilökohtaista muutosta (Leahy 2001).

Muutoksen vastustamisen perusmuodot voivat ilmetä jonkin toimintakokonaisuuden ylläpitämisenä, välttämisenä tai kompensoimisena (Young, Klosko ja Weishaar 2002). Näiden ilmiöiden taustalla voi olla muutokseen liittyviä toivottomuuden tunteita ja negatiivisten tunteiden välttämistä. Ohjattava voi kääntää hankalan asian tai teeman jopa päinvastaiseksi. Esimerkiksi uuden asian kokeilemiseen liittyvän riippuvuuden uhkan henkilö voi kääntää pakonomaiseksi yksin toimeen tulemiseksi.

Moraalinen vastustus ilmenee erilaisten täytymisten kautta, jolloin tavoitteet voivat olla hy- vin epärealistisia ("minun pitäisi olla aina tyyni ja rauhallinen” tai "minun täytyy selvitä työssäni aina erinomaisesti”). Ohjattava voi ajatella, että kyseessä on joko moraalinen epäonnistuminen tai että hän on joutunut uhrin asemaan. Kun on paha olo, syy voidaan nähdä joko itsessä, jolloin attribuointi herättää toivottomuuden tunteita tai syynä voidaan nähdä muiden väärä toiminta, ja se herättää vihan tunteita. Usein nämä tunteet vuorottelevat (Leahy 2001). Nämä työnohjauksessa ilmenevät vastustuksen muodot edellyttävät työnohjaajalta herkkyyttä nähdä toisaalta ohjattavan epärealistiset tavoitteet ja toisaalta toivottomuuden tunteet, jotka liittyvät ammatilliseen toimintaan.

Depressiivinen vastustus ilmenee paradoksaalisesti usein siinä, että henkilö ei pyri mielihyvään ja keskittyy pakonomaisesti menetyksien tai negatiivisten asioiden vatvomiseen. Periaatteessa hän pyrkii tällä menetysten välttämiseen tulevaisuudessa: kun keskittyy negatiivisiin asioihin, henkilö kuvittelee välttävänsä jonkin uuden negatiivisen asian aiheuttaman kivun. Yritykset ylläpitää itsearvostusta kääntyvät usein itseä vastaan: epäonnistumista pelkäävä ei pyrikään suoriutumaan kunnolla, sillä yrittämällä jotakin paljastuisi itsessä kuviteltu pelätty heikkous. Esimerkiksi opiskelija ei mene tenttiin, jotta ei epäonnistuisi tai työntekijä lykkää jatkuvasti jonkin tärkeän työtehtävän aloittamista, koska pelkää epäonnistumista. Perfektionismi voi olla myös tällainen itseä suojeleva toimintatapa. Itseä rajoittavat keinot voivat olla myös sellaisia, että henkilö määrittelee positiiviset vaihtoehdot lapsellisiksi ja naiiveiksi, jolloin niitä kohti ei tarvitse edes pyrkiä (Leahy 2001). Tehtäväkeskeinen esimies voi vältellä henkilökohtaisempien asioiden käsittelyä työpaikalla, jolloin läheisempi vuorovaikutus hänen kanssaan ei toteudu.

Työnohjauksessa keskeistä on työskennellä realististen tavoitteiden hahmottamiseksi ammatillisessa toiminnassa ja samalla on pyrittävä tukemaan ohjattavan ammatillista itsetuntoa. Vastustus on luonnollinen osa kahden asiantuntijan vuorovaikutuksessa ja nimenomaan työnohjaajan on kyettävä tunnistamaan vastustukseen liittyvät ilmiöt, jotta hän voisi toimia adekvaatilla tavalla. Mikäli työnohjaaja ei tunnista vastustusta, hän saattaa reagoida henkilökohtaisesti esimerkiksi loukkaantumalla, jolloin ohjattavan henkilökohtaisen kehittymisen mahdollisuudet siinä tilanteessa käytännössä katoavat. 


\section{TYÖNOHJAUSSUHDE}

$\mathrm{T}$ Työnohjaus suhdetta voidaan tarkastella sekä allianssin eli yhteistyösuhteen että transferenssin ja vastatransferenssin käsitteiden näkökulmasta. Allianssikatkokset tarkoittavat Safranin ja Muranin (2000) mukaan terapeuttisen työskentelyn esteitä ja ongelmia. Myös työnohjaussuhdetta voidaan tarkastella allianssin näkökulmasta, jolloin allianssikatkokset voivat olla jossain määrin samanlaisia kuin terapiasuhteessa. Allianssikatkokset ovat asteeltaan erilaisia. Jotkut katkokset voivat liittyä johonkin tiettyyn vuorovaikutustilanteeseen (esimerkiksi ohjattava on tyytymätön, kun työnohjaaja käyttäytyy tietyllä tavalla), mutta muulloin ongelmia ei ilmene. Katkos voi olla myös hyvinkin pitkään kestävä vaihe työnohjausprosessissa.

Pääasiassa allianssikatkokset voivat liittyä 1) erimielisyyksiin työnohjauksen tehtävistä ja 2) erimielisyyksiin tavoitteista tai 3) työnohjaussuhteeseen. Tavallisimmat katkokset ovat vetäytyminen ja vastustus (Safran ja Muran 2000). Vetäytyminen ilmenee esimerkiksi passiivisuutena ja vastustus usein epäsuorana työnohjauksen kyseenalaistamisena. Työnohjauksessa allianssikatkos edellyttää suhteen tarkastelua, jotta varsinainen työskentely olisi mahdollista. Tämä työskentely perustuu metakommunikaatioon, koska tarkastelun kohteena on työnohjaajan ja -ohjattavan senhetkinen vuorovaikutus ja sen hankaluudet. Työskentelyn tavoitteena on allianssikatkoksen taustalla olevan ydinteeman kohtaaminen, joka voi olla ohjattavan pätevyyteen liittyvä pelko tai pelko oman haavoittuvuuden kohtaamisesta.

Perinteisesti määriteltynä transferenssi on ilmiö, jossa potilas sijoittaa aikaisemmat mielikuvansa varhaisista objektisuhteistaan terapeuttiin (Tähkä 1982). Kognitiivisen terapian näkökulmasta transferenssi tarkoittaa terapiasuhteessa aktivoituneita merkityksellisiä vuorovaikutusskeemoja. Vastatransferenssi tarkoittaa terapeutin tunteita, jotka terapeutti sijoittaa potilaaseen. Toisaalta vastatransferenssi on nähty haitallisena ilmiönä (Tähkä 1996) ja toisaalta luonnollisena osana psykoanalyyttista hoitoa (Carpelan 1987). Modernin psykoanalyyttisen näkemyksen mukaan transferenssissa ilmenevät terapeuttisen suhteen aktivoimat latentit merkitykset ja uskomukset (Bateman \& Fonagy 2003). Nämä voivat kuitenkin olla luonteeltaan täydentäviä, jolloin niillä on informaatioarvoa potilaan tilanteesta. Voidaan todeta, että työnohjauksessa transferenssi-ilmiöt tarkoittavat siis vuorovaikutusprosesseja, jotka ovat luonteeltaan komplementaarisia. Sekä työnohjaaja että ohjattava voivat hyödyntää omia aktivoituneita tunteita, uskomuksia ja merkityksiä informaation lähteenä.

Paralleeli-ilmiö puolestaan tarkoittaa ohjattavan työtilanteen ilmiön siirtymistä työnohjaustilanteeseen. Esimerkiksi esimiehen alainen on vaativa ja tämä ahdistaa esimiestä. Vastaavasti esimies voi työnohjaustilanteessa käyttäytyä vaativasti työnohjaajaa kohtaan, jolloin työnohjaajalla aktivoituvat samantyyppiset reaktiot kuin esimiehellä alaisensa kanssa.

Terapiatilanteessa terapeutti samaistuu potilaaseen ja tämä mahdollistaa myös projektiivisen identifikaation, jolloin potilas sijoittaa itsessään olevaa vierasta terapeuttiin ja usein saa terapeutin toimimaan tavalla, jolloin hän voi kontrolloida tätä ilmiötä. Fonagy, Gergely, Jurist ja Target (2002) kuvaavat käsitteellä vieras minuus (alien self) sitä puolta itsessä, jonka potilas voi sijoittaa terapeuttiin. Mitchell (2000) korostaa sitä, että projektiivinen identifikaatio on nimenomaan vuorovaikutuksellinen ilmiö, jossa ovat mukana kahdensuuntaiset tunteet, fantasia ja mielikuvat. Työnohjauksessa tulisi pyrkiä tunnistamaan näitä vastaavia ilmiöitä, joita ohjattava on omassa työssään kohdannut. Toisaalta työnohjauksessa voivat samat ilmiöt aktivoitua ohjaajan ja ohjattavan vuorovaikutuksessa.

Työnohjaussuhteessa työnohjaajalla (ja ohjattavalla) voivat aktivoitua tyypilliset inhimilliset teemat, jotka voivat liittyä hyväksynnän hakemiseen, hylätyksi tulemisen pelkoon tai erilaisiin vuorovaikutuksen ulottuvuuksiin (vaativuus ja odotukset vuorovaikutuksessa, vastavuoroisuus ja luottamus, assertiivisuus ja uhrautuminen sekä autonomia). Youngin ja muiden (2002) mukaan tavallisimmat hankalat teemat voivat olla hyvin monimuotoisia. Työnohjaajalla voi olla vaikeuksia käyttää erilaisia tekniikoita, koska työnohjaaja pelkää suututtavansa ohjattavan esimerkiksi puuttumalla suoraan johonkin virheelliseen toimintaan. Työnohjaajalla voi olla myös syyllisyyttä tai pelkoa siitä, että ohjattava suuttuisi. Erityisesti narsistisesti toimiva ohjattava aktivoi helposti työnohjaajan huonommuuden tunteet. Rajojen asettaminen voi olla vaikeaa vihamieliselle tai tyytymättömälle ohjattavalle. Rajojen 
asettamisen vaikeus voi ilmetä esimerkiksi vaikeutena lopettaa työnohjausistunnot ajallaan (Young ja muut 2002). Työnohjaajan tavalliset keinot piiloutua vaikeilta teemoilta on piiloutuminen tekniikoiden käyttöön sekä ohjattavan leimaaminen vaikeaksi tapaukseksi (Safran ja Muran 2000). Usein työnohjaajalle hankalia teemoja voivat olla ohjattavan torjuva ja hylkäävä suhtautuminen, riippuvuus, mitätöivä tai arvosteleva suhtautuminen, vaativuus, seksuaalisuuden korostaminen, hyväksikäyttö eri tavoin sekä luottamuksen pettäminen. Nämä ilmiöt koettelevat työnohjaajan omaa haavoittuvuuden tunnetta.

Työnohjaajan omat aktivoituvat tunteet edellyttävät myös tarkastelua. Liittyvätkö työnohjaajan hankalat teemat ohjattavan vastustukseen, oppimisprosessin yksilöllisyyteen, suoriutumiseen tai haavoittuvuuden välttelyyn. Myös työnohjauksessa viha ja seksuaalisuuteen liittyvät tunteet voivat aktivoitua. Työnohjaajalle voi olla hankalaa myös sen arviointi, mitä hän voi vaatia ohjattavaltaan ja milloin hän on liian vaativa. Työnohjaaja voi pelätä konfrontaatio-tekniikan käyttöä varoessaan sitä, ettei ohjattava keskeytä työnohjausta. Hankalaa on myös sen arviointi, mitä voi luvata ohjattavalle työnohjauksen alkaessa. Helposti voi omien erinomaisuuden tunteiden pohjalta luvata ehkä liikoja. Ylipäätään ohjauksen aikana työnohjaaja joutuu miettimään, missä määrin ohjattavan odotuksiin voi vastata ja se edellyttää tiettyä autonomiaa asiantuntijana. Hyväksynnän hakeminen voi vaikuttaa siihen, miten pyrkii miellyttämään ohjattavaa ja sen vuoksi ehkä välttelee hankalien asioiden esille ottoa (Young ja muut 2002).

Työnohjaajan olisi hyvä tunnistaa jokaisen oma yksilöllinen oppimisen prosessi. Jonkun oppiminen voi tapahtua yleisestä yksityiseen, jolloin ensin täytyy olla teoria, käsitteet, mallit ja sen jälkeen on mahdollista tarkastella kokemuksia. Jollakin toisella voi olla päinvastainen oppimisentyyli: hän hahmottaa konkreettisen tilanteen aluksi, kokeilee erilaisia lähestymistapoja ja sen jälkeen etsii yhteyksiä teoriaan ja käsitteisiin. Tärkeää on myös luoda työnohjaukselle jatkuvan arvioinnin ja keskustelun ilmapiiri, jolloin myös työnohjaaja saa palautetta omasta toiminnastaan.

Mearnsin (1991) mukaan työnohjauksen kriittiset kysymykset liittyvät siihen, miten ohjauksessa on lupa käsitellä ohjattavan epävarmuutta ja miten ohjattava on sitoutunut asiakkaisiinsa.
Työnohjaussuhteen alkuvaiheessa työnohjaaja voi määritellä epävarmuuden ja itse-epäilyn käsiteltäviksi asioiksi korostaen tällaisten tunteiden kuuluvan oppimisprosessiin. Tätäkin on hyvä käsitellä prosessin aikana, sillä ohjattava voi olettaa, että jossakin vaiheessa täytyy olla varma omasta osaamisestaan ja hän sulkee käsittelyn ulkopuolelle epävarmuuden tunteensa.

Keskeisimmät konfliktin aiheet psykoterapian työnohjauksessa olivat Ramos-Sanchezin ja muiden (2001) mukaan työnohjaajan ja ohjattavan erilaiset asennoitumiset potilaaseen ja kommunikaation ongelmat (työnohjaajan kriittisyyys, eitukeva ja epäkunnoittava asenne). Lisäksi konflikteja aiheuttivat erimielisyydet työnohjauksen tehtävistä ja toteutuksesta (missä määrin ohjattava kokenut saavansa ohjausta), erilaiset käsitteellistämiset ja hoitosuunnitelmat sekä erimielisyydet koskien psykoterapeutin käytännön työtä. Yleisemminkin työnohjauksen konfliktit voivat liittyä erilaiseen asennoitumiseen asiakkuuteen, ohjattavan käytännön työhön sekä erimielisyyksiin työnohjauksen toteutuksesta.

Työnohjaussuhteessa voivat aktivoitua sekä työnohjaajan että ohjattavan merkitykselliset teemat ja tunteet, jotka voivat tuntua hankalilta käsitellä. Kuitenkin näiden teemojen käsittely on tarpeellista ohjattavan työn ymmärtämisen näkökulmasta ja työnohjauksen sujumisen takaamiseksi. Tärkeitä piirteitä työnohjaajalla ovat 1) kyky yhdistää tietämys ja taidot, 2) sensitiivisyys ja aktiivinen kuuntelu ja 3) työnohjaajan itsereflektion kyky (Sloan 1998). Ohjattavan kyky hyötyä työnohjauksesta lisääntyy kokemuksen myötä ja kokeneemmat ohjattavat arvioivat allianssin työnohjaussuhteessa paremmaksi (Ramos-Sanchez ja muut 2001). Tämä voi olla yhteydessä myös kollegiaalisuuden kasvuun.

\section{REFLEKTIIVISYYS TYÖNOHJAUKSESSA}

$\mathrm{R}$ eflektiivisyys psykoterapian työnohjauksessa tarkoittaa ohjattavan potilastilanteen ilmiöiden ymmärtämisen prosessia, jolloin fokuksessa ovat terapeutin toiminnot, emootiot ja ajatukset sekä hänen suhteensa potilaaseen. Ohjaus toteutuu erityisesti tilanneanalyysien kautta, jolloin lähtökohtana voi olla ohjattavan potilastilanteen kriittinen kohta (Neufeldt, Karno ja Nelson1996). Vastaavasti eri alojen asiantuntijoiden työnohjauksessa lähtökoh- 
tana on ohjattavan työtilanne, jota tarkastellaan ohjattavan toimintojen, emootioiden ja ajatusten sekä suhdetekijöiden avulla.

Neufeldt ja muut (1996) haastattelivat reflektion ja työnohjauksen kansainvälisiä auktoriteetteja Schöniä, Skovholtia, Ronnestadia, Copelandia ja Hollowayta saadakseen koottua näiden käsitykset reflektiosta työnohjauksessa. Jokainen kuvasi reflektioprosessin alkua tilanteena, jossa havaitaan jokin ongelma työprosessissa, ja se herättää epävarmuutta sen suhteen, mistä on kyse. Edellytykset reflektioprosessin alkamiselle liittyvät ohjattavan persoonaan ja kognitiiviseen kapasiteettiin: haastetellut auktoriteetit olivat yhtä mieltä siitä, että ohjattavat eroavat reflektiokyvyn kapasiteetin osalta. Ratkaisevaa on työnohjaajan kyky fokusoida. Toisaalta työnohjaukseen liittyvien tekijöiden kehitysvaihe vaikuttaa asioiden käsittelyprosessiin: onko suhde riittävän turvallinen ja ovatko edellytykset yhteiselle tarkastelulle syntyneet. Ilmiön tarkasteluprosessissa fokus on ohjattavan sisäisessä maailmassa: hänen ajatuksissaan, tunteissaan, toiminnassaan ja toisaalta terapiasuhteen tarkastelussa. Erityisesti reflektoidaan sitä, miten ohjattava on toiminut ja mitkä ovat toiminnan merkitykset. Työnohjaajan kysymysten avulla haetaan vastausta siihen, millaisia merkityksiä ohjattava on hakenut työtilanteessa. Tärkeää on myös tarkastella, kuinka ohjattavan avoimuus potilaan tai asiakkaan ymmärtämiselle on säilynyt ja missä määrin haavoittuvuutta on pystytty kohtaamaan. Jälleen samat kysymykset ovat mukana myös ohjausprosessissa: ymmärtääkö työnohjaaja ohjattavansa toimintaa, ja missä määrin he pystyvät käsittelemään ohjattavan haavoittuvuutta työtilanteessaan. Ymmärrys voi perustua teoriaan ja toisaalta työnohjaajan kokemukseen. Onnistuneen reflektioprosessin seurauksen ohjattavan havaitsemisprosessi ilmiön suhteen muuttuu ja sitä kautta hänen toimintavalmiutensa vastaavissa tilanteessa lisääntyvät ja pitkällä tähtäimellä hänen kykynsä havaita merkityksiä lisääntyy (Neufeldt ja muut 1996).

\section{TYÖNOHJAUKSEN TEHTÄVÄT}

Olennainen osa työnohjausprosessia on toisaalta tavoitteenasettelu ja toisaalta palautesysteemien onnistunut toteutus. Selkeät työnohjauksen tavoitteet määrittävät suunnan, johon ohjat- tava omassa työssään voi pyrkiä. Toimiva palautekäytäntö puolestaan antaa ohjattavalle käsityksen siitä, miten hän etenee ammatillisesti. Palautteen onnistuminen edellyttää siis sekä tavoitteiden määrittelyä että jatkuvaa arviointia siitä, miten ohjattava edistyy tavoitteiden mukaisesti (Lehrman-Waterman ja Ladany 2001). Selkeät tavoitteet ovat yhteydessä myös työnohjaussuhteen laatuun, ohjattavan käsitykseen itsestään asiantuntijana sekä ohjattavan tyytyväisyyteen työnohjaukseen (Lehrman-Waterman ja Ladany 2001).

Työnohjaussuhteen alkuvaiheissa korostuvat usein käytännön toiminnan näkökulmat, käsitteellistäminen ja ohjattavan ammatillisen roolin selkeyttäminen. Vähitellen mukaan tulee ohjattavan emotionaalisen tietoisuuden tarkastelu, jolloin tavoitteena on se, että ohjattava kykenee käyttämään omia sisäisiä prosesseja adekvaatteina työvälineinä. Työnohjaus on myös jatkuvan reflektoinnin oppimisen väline. Työnohjattava voi havaita reflektiivisen ajattelun kehittymisen tapahtuvan siirtymisenä luokittelevasta ja syy-seuraussuhteisiin perustuvasta päättelystä asioiden ja ilmiöiden tarkasteluun moniulotteisina ja -tasoisina ilmiöinä. Tällöin tunnistetaan viitekehyksen merkitys sekä ymmärretään oman toiminnan, tulkinnan ja ajattelun merkitys vuorovaikutusprosessissa (Holloway 1997, ks Tiuraniemi 2001).

Työnohjaajan toimintaa voidaan kuvata myös sosiaalisen roolin mallin mukaan, jolloin tarkastellaan työnohjaajan tehtäviä, rooleja ja käyttäytymistä ohjaustilanteessa. Työnohjaajan perusroolit ovat opettajan, reflektoijan ja konsultin roolit. Työnohjaustilanteessa suhteen alkuvaiheessa voi korostua opettajan ja opiskelijan roolit, mutta prosessin edetessä roolit ja positiot perustuvat enemmän yhteistyösuhteeseen. Prosessin myöhemmässä vaiheessa korostuvat enemmän työnohjaajan reflektoijan ja konsultin roolit.

Työnohjauksen ensimmäinen funktio on Hollowayn (1997) mukaan monitorointi ja arviointi, joka tarkoittaa esimerkiksi ohjaajan antamaa palautetta ohjattavan taitojen, käsitteellistämisen, ammatillisen roolin, emotionaalisen tietoisuuden ja reflektion osalta. Palautteenannon tulisi toteutua jatkuvasti, käytännössä palaute annetaan usein epäsuorasti. Lähtökohtaisesti ohjattavan työn tarkastelu on yhteistä työn ongelmakohtien pohdintaa, jossa tarkastelun ja arvioinnin fokus voi vaihdella. Neuvonnan ja ohjannan osalta tärkeää on arvioida se, milloin ohjattava tarvitsee 
neuvoja ja milloin pohditaan yhteisesti jotakin ongelmakohtaa. Mallittaminen tarkoittaa sekä käytännön toimintamallien tarjoamista että teoreettisten, käsitteellisten mallien hahmottamista. Konsultointi on prosessi, jossa haetaan vastausta johonkin kysymykseen. Tämä on yhteistyötä, jossa määritellään tarkemmin työnongelma, siihen liittyvät tekijät, ilmiön tarkempi olemus sekä suuntaudutaan vaihtoehtoisiin toimintamalleihin, joita pohditaan edelleen yhdessä. Tärkeä osa työnohjausta on tuen antaminen ja hankalien tunteiden ja asioiden jakaminen. Tavoitteena on myös ohjattavan jaksamisesta huolehtiminen (Holloway 1997).

$\mathrm{T}$

Dimintaympäristö on selvästi jäänyt vähemmälle huomiolle sekä työnohjauksen että psykoterapian käytäntöjen tutkimuksessa (Davy 2002). Toimintaympäristön reflektio on kuitenkin tarpeellinen koko työprosessin ymmärtämisen kannalta (Hardy, Phillips ja Clegg 2000). Mikäli työnohjaaja on tottunut työskentelemään yksin ilman työyhteisön tukea, saattaa tällöin ohjattavan työympäristön odotusten vaikutusten tarkastelu jäädä vähemmälle. Sairaalaympäristössä tilanne voi olla toinen. Landmarkin, Hansenin, Bjonesin ja Bohlerin (2003) mukaan hoitajat korostivat, että työnohjauksessa oma rooli selkeytyy ja työnohjauksessa voi käsitellä työympäristön asettamia odotuksia. Lisäksi hoitajien arvioinnit omien taitojensa kehittymisestä liittyivät tavoitteiden ja arvioinnin lisäksi taitoon yhdistää teoria ja käytäntö sekä taito reflektoida työtilanteita. Työyhteisön työnohjauksessa eri tilanteiden tarkastelu suhteessa perustehtävän sujumiseen on ensiarvoisen tärkeää.

Työnohjauksen tukena täytyy olla monia erilaisia muotoja: kollegiaaliset keskustelut, vertaisryhmien vuorovaikutukset, tapausseminaarit ja workshopit (Ronnestad et al 1997). Johnson ja Stewart (2001) totesivat, että ohjattavien tyytyväisyys oli suurempaa, mikäli heillä oli mahdollisuus työnohjaukselliseen vertaistukeen. Tästä näkökulmasta tärkeätä on luoda mahdollisuus myös ryhmätyönohjaukseen, jolloin vertaistuki mahdollistuu. Tällöin ryhmäilmiöiden tuntemus onkin edellytys työnohjaajana toimimiselle. Kokonaisuudessaan voidaan todeta, että työnohjauksen tehtävät painottuvat eri tavoin työnohjausprosessin eri vaiheissa ja tärkeää onkin, että työnohjaaja osaa ottaa huomioon työnohjauksen prosessiluonteisuuden.

\section{TYÖNOHJAUS AMMATILLISEN KEHITYKSEN TUKENA}

$\mathrm{T}$ yönohjausta voidaan tarkastella ammatillisen kehityksen vaiheiden tarkastelun näkökulmasta. Persoonallinen kehitys luo mahdollisuuksia ammatilliselle kehitykselle ja se toteutuu pitkälti myös työnohjausprosessin aikana (Zorga 2003).

Hawkins \& Shohet (1991) ovat kuvanneet psykoterapeutin ammatillisen kehityksen vaiheittaisena. Ensimmäinen vaihe on noviisivaihe, jota seuraa potilaskeskeinen vaihe ja kolmantena prosessikeskeinen vaihe ja lopulta taitavan ammatillisen toiminnan vaihe. Tätä vaihemallia voidaan soveltaa yleisemminkin asiantuntijuuden kehittymisen tarkasteluun.

Noviisivaiheessa asiantuntija keskittyy itseensä ja saattaa ahdistuneena miettiä, osaako työnsä. Hän voi olla riippuvainen ohjaajastaan ja odottaa ohjaustilanteessa struktuuria sekä positiivista palautetta. Asiakaskeskeisessä vaiheessa ohjattavan huomio keskittyy asiakkaaseen, jolloin hän miettii, voiko auttaa asiakastaan. Toiminnassa vaihtelee liiallinen tukeutuminen ja korostettu autonomia, jotka toisaalta ilmaisevat emotionaalista tarvetta ohjauksessa ja toisaalta epäilyjä omasta osaamisesta. Työnohjauksessa voi olla myös kriisivaihe, jolloin ohjattava epäilee myös työnohjaajaansa, jonka näkee riittämättömänä omiin tarpeisiinsa nähden. Prosessikeskeisessä vaiheessa huomion kohteena on erityisesti yhteistyösuhde asiakkaan kanssa, jolloin ohjattava miettii asiakkaan, hänen ongelmansa ja tekniikoiden vuorovaikutusta. Kyky nähdä kokonaisuuksia on myös kehittynyt. Työnohjaussuhteessa korostuu tässä vaiheessa kollegiaalisuus. Taitavan toiminnan vaiheessa asiantuntija kykenee keskittymään kokonaistilanteeseen, jolloin hän tarkastelee, miten työtilanteissa ilmenevät prosessit ovat suhteessa toisiinsa (Hawkins ja Shohet 1991; Tiuraniemi 1994 ja 2002).

Skovholtin ja Ronnestadin (1995) mukaan tietoisuus työn monimutkaisuudesta on keskeinen tekijä, joka vaikuttaa siihen, onko ammatillinen kehittyminen jatkuva prosessi vai tapahtuuko ylirasittumisen seurauksena ammatillinen pysähtyminen. Muita kehityksen suuntaan vaikuttavia tekijöitä ovat esimerkiksi motivoituminen työhön. Prosessia voi vaikeuttaa motivaation heikkous tai liiallinen työhön sitoutuminen. Vuorovaikutuksellinen työskentely saattaa herättää tunteita, 
jotka edellyttävät henkilökohtaista työstämistä. Itsestään huolehtiminen koko ammatillisen toiminnan ajan on tarpeen. Asennoituminen monimutkaisuuteen on usein yhteydessä siihen, miten haastavana kokee työnsä ja suhtautuminen voi olla hyvinkin yksilöllisesti muotoutunutta. Yksilöllistä on myös se, miten suhde työn aktivoimiin negatiivisiin tunteisiin muotoutuu: ammatillisen kehityksen eri vaiheissa voi joutua mukautumaan erilaisiin työn herättämiin negatiivisiin tunteisiin. Kehitystavoitteita on hyvä prosessoida myös koko ammatillisen toiminnan ajalta. Kehityksen suuntaan vaikuttavat myös koulutukseen tai ammatilliseen toimintaympäristöön liittyvät rakenteelliset tekijät. Kun ympäristö tarjoaa tukea ammatilliselle kehittymiselle, yksilön on helpompi toteuttaa omia sisäisiä kehittymisen prosesseja.

Monet tekijät vaikuttavat siihen, perustuuko ammatillinen kehittyminen jatkuvaan reflektioon vai onko seurauksena ylirasittuminen. Ylirasittuminen voi johtaa ammatillisen kehittymisen ennenaikaiseen pysähtymiseen ja seurauksena voi olla näennäinen kehittyminen, jolloin ammatillisen kehittymisen jotkut vaiheet toteutuvat vaillinaisesti. Tällaisen tilanteen tunnistaminen voi auttaa takaisin reflektiiviseen toimintaan, mutta voi johtaa myös kyynistymiseen ja jatkuvaan tyytymättömyyteen. Tästä näkökulmasta työnohjauksessa on huomioitava, miten tuetaan ohjattavan jaksamista ammatillisen kehittymisen eri vaiheissa.

Ronnestad, Orlinsky, Parks ja Davis (1997) totesivat, että psykoterapian alueella ammatillisen kehityksen myötä psykoterapeutti ryhtyy yhä useammin työnohjaajaksi. Vastaavasti voidaan ajatella, että työnohjaajakoulutuksen hankkiminen ja työnohjaajana toimimisen aloittaminen on siten yksi vaihe asiantuntijan ammatillisessa kehityksessä. Ronnestad ja muut (1997) tutkivat myös, miten ohjaajan luottamus omaan taitoon ohjata kehittyy. Luottamuksen lisääntymistä ei selittänyt ikä, sukupuoli, toimintaorientaatio tai toteutettu terapiamuoto. Terapeutin oma arvio terapeuttitaidoistaan sekä toteutuneiden työnohjausten määrä selittivät luottamuksen lisääntymistä. Voidaan olettaa, että työnohjaajaksi ryhtyminen on yhteydessä siihen, missä määrin asiantuntija luottaa omaan ammatilliseen osaamiseensa. Työnohjaajaksi ryhtyminen on kuitenkin ajankohtaista ammatillisen kehityksen myöhemmissä vaiheissa.

\section{TYÖNOHJAUS PROSESSINA}

Gilbert ja Evans (2000) ovat kehittäneet psykoterapian työnohjauksen vaiheteorian integratiivisesta näkökulmasta pitäen lähtökohtana inhimillisen kehityksen eri vaiheita. Myös tätä mallia voidaan soveltaa yleisemminkin työnohjausprosessiin. Ensimmäisessä vaiheessa keskeistä on turvallisuuden ja varmuuden tunteiden saavuttaminen, jolloin osaamisen tunne voi olla väkisin ylläpidettyä. Kriittisiä tilanteita ovat kriisivaiheet omassa työssä tai mikäli asiakas koettelee asiantuntijan osaamista testaamalla tämän selviytymiskykyä hankalissa tilanteissa tai yleensäkin tilanteet, jotka synnyttävät epävarmuuden tunteita. Oma käsitys ”oikein tekemisestä” voi olla hyvinkin vahva. Työnohjaaja on usein idealisoitu objekti, jolta odotetaan vahvasti apua. Usein odotuksiin liittyvä paralleeliprosessi toteutuu: esimerkiksi asiakkaan odotukset siirtyvät vahvoina odotuksiksi työnohjauksessa tuen tarjoamisesta. Työnohjaajan tulee tukea ohjattavan pyrkimyksiä objektiiviseen observointiin. Hankaluutena poulestaan voi olla työnohjaajan liiallinen mukautuminen ohjattavan tilanteisiin (Gilbert ja Evans 2000).

Ohjauksen ydinvaiheessa on keskeistä ammatillisen identiteetin rakentuminen, jolloin ongelmat usein liittyvät siihen, että ohjattavalla aktivoituvat tietyn tyyppisten henkilöiden ja asiakkaiden kanssa omaan persoonaan liittyvät ahdistukset. Tällöin ohjattava saattaa pohtia asiakassuhteen lopettamista tai sen pakotettua jatkamista. Usein empatian puute leimaa tässä tilanteessa prosessia. Yleisesti ongelmana voi olla kompetenssiin liittyvät kysymykset, jolloin kompetenssin tunteen ylläpito voi olla väkinäistä. Käsitteellistäminen tai tekniikat korostuvat työnohjauksessa, mutta samanaikaisesti ohjattava kamppailee omien rajojen ja mahdollisuuksien arviointien kanssa (Gilbert ja Evans 2000).

Intersubjektiivisen vaiheen keskeinen piirre on suuntautuminen toiseen, jolloin ongelmina voivat olla erilaiset vuorovaikutuksen jumit ja hankaluudet. Nämä voivat ilmetä työnohjauksessa allianssikatkosten kautta. Taustalla olevat keskeiset teemat liittyvät haavoittuvuuteen ja aggression kohtaamiseen (Gilbert ja Evans 2000).

Verbaalisessa vaiheessa ohjattava osaa paljon: hän kykenee reflektoimaan kokemuksiaan ja verbalisoimaan niitä hyvin ja lisäksi hänen tietonsa ja taitonsa ovat laaja-alaiset. Tässä vaihees- 
sa sudenkuoppana voi kuitenkin olla omien vaikeuksien jakaminen ohjaajan ja työnohjausryhmän muiden jäsenten kanssa. Halu ylläpitää osaamisen ja kompetenssin tunnetta on niin keskeinen, että vaikeuksien tunnistaminen ei ikään kuin olekaan mahdollista. Voi olla, että ohjattava pyrkii työnohjauksessa antamaan vaikutelman siitä, että on pystyvä ja osaava, vaikka työtilanteessa tilanne onkin päinvastainen. Haaste työnohjauksessa on kuitenkin oman rajallisuuden ja haavoittuvuuden kohtaaminen, epätäydellisyyden sietäminen ja omasta jaksamisesta huolehtiminen (Gilbert ja Evans 2000).

Zorga (2003) tarkastelee työnohjaajaksi kehittymistä. Kun henkilö aloittaa työnohjaajana, hänellä on sama epävarmuus kohdattavana kuin kenellä tahansa ammatillisessa toiminnassa aloittavalla. Epävarmuutta hallitakseen ohjaaja suuntautuu usein työnohjauksen määrittelyyn ja selkeyttämiseen, mahdollisuuksien, rajojen ja sääntöjen määrittelyyn sekä tekniikoiden korostamiseen. Hänellä voi olla vaikeuksia ymmärtää työnohjausprosessia tai ylipäätään ohjattavan tilannetta. Fokus on helposti vain työn kohteessa tai asiakkaassa ja toimintaa ohjaa oma viitekehys, johon hän yrittää vetää ohjattavan mukaan (Zorga 2002).

Roolin syvenemisen vaiheessa tietoisuus omasta vallasta ja vaikuttavuudesta lisääntyy, samoin käsitys omista heikkouksista. Epävarmuuden sieto kasvaa, jolloin uskallus riskinottoon lisääntyy. Samoin kiinnostus ohjattavan ammatilliseen kasvuun lisääntyy. Fokus siirtyy yhä enemmän ohjattavaan, hänen taitonsa on helpompi nähdä lähtökohtana ja myös prosessien merkitys on helpommin nähtävissä. Motivaatio työnohjaajana toimimiseen kuitenkin vaihtelee (Zorga 2003).

Kolmannessa vaiheessa motivaatio työnohjaajana toimimiseen on korkea ja se heijastuu myös ohjaussuhteeseen. Ohjattavan oppimisen prosessi kiinnostaa ja kyky sopeuttaa omaa toimintaa myös ohjattavan tilanteeseen lisääntyy. Oma vaikuttavuus nähdään selvemmin ja itsellä on pätevämpi olo. Työnohjaus on selvemmin osa omaa ammatillista toimintaa (Zorga 2003).

Neljäs vaihe on hallinnan vaihe. Toiminta on joustavaa, eikä ohjaaja preferoi välttämättä jotakin toimintatyyliä, vaan pystyy mukauttamaan toimintaansa. Prosessien eri vaiheet ovat selvemmin mielessä, ja omiin virheisiin on helpompi suhtautua. Oma tyyli on löytynyt, ja tämä heijastuu ohjattavaan siten, että tämän tunne autonomiasta, varmuudesta ja tuesta lisääntyy. Kehitys on kuitenkin nähtävä prosessina ja eri alueilla prosessi voi edetä eri tavoin: jollakin alueella työnohjaaja voi toimia neljännen vaiheen mukaisesti, mutta jollakin alueella hänen toimintansa saattaa muistuttaa alkuvaiheen ohjaajan toimintaa (Zorga 2003).

Gilbert ja Evans (2000) ovat kuvanneet myös ohjattavan erilaisia toimintamalleja, jotka voivat kuvata ohjattavan tilannetta. Yksi tällainen toimintatapa on etukäteispaketointi, jolloin ohjattava on hyvin valmistautunut ohjaukseen ja hän esittää asiansa valmiina pakettina, johon työnohjaajan on vaikea lisätä mitään. Ohjattavan odotukset ovat selkeät, ja käsitys ohjauksesta selkeä; mutta tämä asennoituminen voi olla kuitenkin myös suoja epävarmuutta vastaan. Tällöin haaste työnohjauksessa on se, miten pystyä liikkumaan uusille alueille, joihin saattaa liittyä epävarmuutta ja osaamattomuudenkin tunteita. Toista toimintatapaa voi kuvata informaation tulvana, jolloin ohjattava kertoo yksityiskohtaisesti tilanteista olettaen, että ohjaaja ei ymmärrä muutoin. Tällöin työnohjaajan vaikeutena on kokonaiskuvan saaminen sekä vaikeus keskittyä olennaiseen. Ohjattava voi myös jatkuvasti torjua työnohjaajan ehdotuksia. Hän saattaa todeta, että on jo kokeillut työnohjaajan ehdottamaa keinoa. Taustalla ohjattavalla voi olla uskomus siitä, että pitää tietää kaikki asiat ja ilmiöt, ilman että kukaan opettaa niitä. Tällöin työnohjauksessa fokus on hyvä suunnata ohjattavan sisäisiin prosesseihin, jolloin voidaan pohtia etukäteistietämisen vaatimusta. Vastaavasti ohjattavan sisäisten prosessien tarkastelua edellyttää tilanne, jossa ohjattava sijoittaa ongelman työnohjaajaan. Tällöin työnohjaajan on oltava avoin oman toiminnan kritiikille ja toisaalta avoin sille mahdollisuudelle, että ohjattava työstää jotain omaa sisäistä hankaluuttaan sijoittamalla ongelman työnohjaajaan. Tämä on myös terapeuttisen testauksen perustilanne: kun potilas asettaa terapeuttinsa hankalaan tilanteeseen, hän voi arvioida, miten terapeutti selviää siitä. Mikäli terapeutti pystyy toimimaan tilanteessa ahdistumatta, potilas voi odottaa terapeutin kestävän myös potilaan sisäisiä ahdistuksia. Mikäli ohjattava on jatkuvasti kriittinen työnohjaajan lähestymistapaa kohtaan, on ohjattavalle tarjottava mahdollisuus jakaa ajatuksiaan ja ajatteluaan. Myös arvostamisen osoittaminen on tärkeää. Jos ohjattava tekee henkilökohtaisen hyök- 
käyksen työnohjaajaa vastaan, tämä edellyttää “tässä ja nyt” -työskentelyä metatasolla (Safran ja Muran 2000). Ohjattava voi myös nähdä herkästi epäonnistumisen syyt itsessään ja tuo sen myös esille. Tällöin työnohjauksessa on vaarana työnohjaajan ylisuojeleva asenne. Fokus on suunnattava vuorovaikutukseen ja konkreettiseen ohjattavan tilanteiden käsittelyyn (Gilbert ja Evans 2000).

\section{YHTEENVETO}

Työnohjausta on tarkasteltava prosessina, jossa on erilaisia vuorovaikutusilmiöitä. Ohjattava voi toimia työnohjauksessa hyvinkin yksilöllisesti. Taustalla voivat olla erilaiset hankalat teemat, joita vastaan ohjattava yrittää suojautua. Osaamattomuuden tunteet tai oma haavoittuvuus ovat usein tällaisia teemoja, joiden käsittelyä turhaan vältellään työnohjauksessa. Työnohjaajan onkin oltava tietoinen näistä ilmiöistä, jotta hän pystyisi tukemaan ohjattavaansa vaikeidenkin asioiden käsittelyssä. Työnohjaus on tilanne, jossa ohjaajalla on valtaa ja auktoriteettia ohjattavaan nähden. Tämä asetelma voi myös aktivoida erilaisia vuorovaikutusmalleja, joiden tarkastelu on välttämätöntä työnohjauksessa. Vastustus, erilaisten merkityksellisten vuorovaikutusskeemojen aktivoituminen ja suojautuminen vaikeita teemoja vastaan ovat luonnollisia työnohjaukseen kuuluvia ilmiöitä, joita on hyvä tunnistaa ja käsitellä prosessin aikana.

Kokonaistavoite työnohjauksessa on se, että ohjattava oppii kunnioittamaan omaa osaamistaan ja osaa asettaa realistisia kehittymisen tavoitteita omalle toiminnalleen. Työnohjausprosessin aikana voi tapahtua merkittävääkin ammatillista kehitystä. Kehitysprosessi voi olla polveileva ja monivaiheinen, mikä heijastuu myös työnohjaajan ja ohjattavan yhteistyösuhteeseen. Vuorovaikutuksellinen ja reflektoiva työskentely auttaa ohjattavaa tunnistamaan omaa osaamistaan ja kehitysmahdollisuuksiaan sekä huolehtimaan omasta jaksamisestaan työssään. Työnohjaus on haaste myös työnohjaajalle, ja hänen on myös pystyttävä kohtaamaan itsessään aktivoituneita merkityksellisiä, ehkä vaikeitakin teemoja ja tunteita. Työnohjaajana toimiminen tarjoaa mahdollisuuden myös omaan ammatilliseen kehitykseen. Parhaimmillaan työnohjaus on prosessi, jossa molemmat osapuolet kehittyvät ammatillisesti ja käyvät läpi merkittävän oppimisprosessin.

\section{LÄHTEET}

Aron, L. (1996). A Meetings of minds: mutuality in psychoanalysis. New York: The Analytic Press.

Bateman, A.W. \& Fonagy, P. (2003). The development of an attachment-based treatment program for borderline personality disorder. Bulletin of Menninger Clinic, 67, 187-211.

Carpelan, H. (1987). Terapeutin tunnereaktiot potilaaseen ja niiden merkitys hoidossa. Duodecim, 103, 1370-1378.

Corn, A. (2001). The Interplay between therapy and supervision. Journal of Contemporary Psychotherapy, 31, 257-268.

Ellis, M.V., Ladany, N., Krengel, M., \& Schult, D. (1996). Clinical supervision research from 1981 to 1993: A methodological critique. Journal of Counseling Pscyhology, 43, 35-50.

Fonagy, P., Gergely, G., Jurist, E.L. \& Target, M. (2002). Affect regulation, mentalization, and the development of the self. New York: Other Press.

Freitas, G.J. (2002). The impact of psychotherapy supervision on client outcome: a critical examination of 2 decades of research.

Psychotherapy: Theory, Research, Practice, Training. 39, 354-367.

Gendlin E.T. (1996). Focusing-Oriented Psychotherapy, A Manual of the Experiental Method. New York: Guilford.

Greenberg L.S., Rice, L.N. \& Elliot R.E. (1993). Facilitating Emotional Change. New York: Guilford.

Guidano, V. (1991). The self in process. New York: Guilford.

Hardy, C., Phillips, N. \& Clegg, S. (2000). Reflexivity in organization and management theory: A study of the production of the research subject. Human Relations, 54, 531-560.

Holloway, E.L. (1997). Structures for the analysis and teaching of supervision. Teoksessa Watkins, C.E.Jr. Handbook in psychotherapy supervision. New York: Wiley, 249-276.

Hyrkäs, K. (2002). Clinical supervision and quality care. Examining the effects of team supervision in multi-professional teams. Acta Universitatis Tamperensis 869.

Johnson, W.B. (2002). The intentional mentor: Strategies and guidelines for the practice of 
mentoring. Professional Psychology: Research and Practice, 33, 88-96.

Keskinen, S. (toim). (2002). Työelämän vaatimukset ja työnohjauksen mahdollisuudet. Turun yliopiston täydennyskoulutuskeskus. Sarja B, Raportit ja selvitykset.

Landmark, B.T., Hansen, G.S., Bjones, I., \& Bohler, A. (2003). Clinical supervision - factors defined by nurses as influential upon the development of competence and skills in supervision. Journal of Clinical Nursing, 12, 834-841.

Leahy, R.L. (2001). Overcoming resistance in cognitive therapy. New York: Guilford.

Lehrman-Waterman, D. \& Ladany, N. 2001. Development and validation of the evaluation process within supervision inventory. Journal of Counselling Psychology, 48, 168-177.

McKinney, M. 2000. Relational perspective and the supervisory triad. Psychoanalytic Psychology, 17, 565-584.

Mitchell, S.A. (2000). Relationality. From attachment to intersubjektivity. Vol 20 in Relational Perspectives Book Series. Hilsdale, NJ, London: The Analytic Press.

Neufeldt, S.A., Karno, M.P., \& Nelson, M.L. (1996). A Qualitative study of experts' conceptualization of supervisee reflectivity. Journal of Counselling Psychology, 43, 3-9.

Padesky, C.A. 1996. Developing cognitive therapist competency: teaching and supervision models. Kirjassa P.M.Salkovskis: Frontiers of cognitive therapy. New York: Guilford.

Paunonen-Ilmonen, M. (2001). Työnohjaus: toiminnan laadunhallinnan varmistaja. WSOY.

Ramos-Sanchez, L., Esnil, E., Goodwin, A., Riggs, S., Touster, L.O., Wright, L.K., Ratanasiripong, P. \& Rodolfa, E. (2002). Negative supervisory events: Effects on supervision and supervisory alliance. Professional Psychology: Research \& Practice, 33, 197202.

Ronnestad, M.H., Orlinsky, D.E., Parks, K. Davis, J.D. and SPR Collaborative Research Network (1997). Supervisors of Psychotherapy: Mapping experience level and supervisory confidence. European Psychologist, 2, 1919-201.
Safran, J.D. \& Muran, J.C. (2000). Negotiating the therapeutic alliance: A Relational treatment guide. New York: Guilford.

Schön, D. (1983). The reflective practitioner: how professionals think in action. New York: Basic Books.

Segal, Z.V., Williams, J.M.G. \& Teasdale, J.D. (2002). Mindfulness-based cognitive therapy for depression. A new approach to preventing relapse. New York: Guilford.

Sloan, G. (1998). Clinical supervision: Characteristics of a good supervisor. Nursing standard, 12, 42-46.

Temple S., \& Bowers, W.A. (1998). Supervising Cognitive Therapists From Diverse Fields. Journal of Psychotherapy: An International Quarterly, 12, 139-151

Tiuraniemi, J. (2001). Työnohjaus. Teoksessa S. Kähkönen, I. Karila \& N. Holmberg (toim.). Kognitiivinen psykoterapia, 337-346. Duodecim.

Tiuraniemi, J. (2002). Reflektiivisyys asiantuntijan työssä. Teoksessa P. Niemi \& E. Keskinen (toim.). Taitavan toiminnan psykologia. Turun yliopiston psykologian laitoksen julkaisuja.

Tähkä, V. (1982). Psykoterapian perusteet psykoanalyyttisen teorian pohjalta. 3 p.WSOY.

Tähkä V. (1996). Mielen rakentuminen ja psykoanalyyttinen hoito. WSOY.

Young, J.E., Klosko, J.S. \& Weishaar, M.E. (2002). Schema therapy. A Practitioner's guide. New York: Guilford.

Zorga, S. (2002). Professional supervision as a mean of learning and development of counselors. International Journal for the Advancement of Counselling, 24, 261-274

Zorga, S. (2003). Stage and contextual approaches to development in professional supervision. Journal of Adult Development, 10, 127-134.

Artikkeli saapui toimitukseen 26.6.2005 Se hyväksyttiin julkaistavaksi toimituskunnan kokouksessa 10.1.2005. 